\title{
Microcalorimetric Study of Acetylcholine and Acetylthiocholine Hydrolysis by Acetylcholinesterase
}

\author{
Paulo Alexandre A. de Almeida Neves*, Eliane Novato Silva, Paulo S. L. Beirão \\ Biochemistry and Immunology Department, Federal University of Minas Gerais, Belo Horizonte, Brazil \\ Email: *neves.p.a.a.a@gmail.com
}

How to cite this paper: de Almeida Neves, P.A.A., Silva, E.N. and Beirão, P.S.L. (2017) Microcalorimetric Study of Acetylcholine and Acetylthiocholine Hydrolysis by Acetylcholinesterase. Advances in Enzyme Research, 5, 1-12.

https://doi.org/10.4236/aer.2017.51001

Received: January 7, 2017

Accepted: March 6, 2017

Published: March 9, 2017

Copyright ( $) 2017$ by authors and Scientific Research Publishing Inc. This work is licensed under the Creative Commons Attribution International License (CC BY 4.0).

http://creativecommons.org/licenses/by/4.0/ (c) (i) Open Access

\begin{abstract}
Acetylcholinesterase (AChE) is an important enzyme responsible for the cleavage of acetylcholine. Studies of the activity of this enzyme use an artificial substrate, acetylthiocholine, because a product of its catalysis, thiocholine, readily generates a light absorbing product upon reaction with Elman's reagent 5,5'-dithiobis-(2-nitrobenzoic acid (DTNB). The hydrolysis of acetylcholine cannot be assayed with this method. The isothermal titration calorimetry can assay the hydrolysis of both substrates, without requiring additional reagents other than the enzyme and the substrate. To compare kinetic values obtained in the hydrolysis of acetylcholine (ACh) and acetylthiocholine (ATCh), with carbaryl acting as inhibitor, a calorimetric technique was used to evaluate kinetic properties of the two reactions. This method can show the hydrolysis of both substrates by the heat exchange that occurs during catalysis. In addition, it allowed the assessment of the AChE inhibition by carbaryl, a common insecticide. The results show a similarity between values obtained with both substrates, which are slightly higher for acetylcholine, the enzyme natural substrate. Enzymatic parameters values from ATCh and ACh were similar to each other and inhibitory constants using carbaryl were also similar, displaying that any approach to ACh is feasible using ATCh. The results obtained from ITC show the precision achieved by the calorimetric method.
\end{abstract}

\section{Keywords}

Acetylcholinesterase, Acetylcholine, Acetylthiocholine, Isothermal Titration Calorimetry, Carbaryl

\section{Introduction}

Acetylcholinesterase (AChE) (3.1.1.7) is one of the best studied enzymes found in scientific literature, partly due to its physiological role in the neurotransmis- 
sion process and also to the remarkably high efficiency displayed by AChE, which has a large turnover number [1] [2]. AChE is responsible for the cleavage of acetylcholine (ACh) within the neuromuscular junction and the synaptic cleft in the central nervous system of both vertebrates and invertebrates [3] [4]. It is highly conserved along evolution. Due to its importance in insects, it is a target for many substances used as pesticides [5]. AChE inhibitors have pharmaceutical and commercial importance, and side effects should be an important issue to be considered [6].

Carbaryl is a carbamate organic compound and classical noncompetitive inhibitor of AChE, with widespread use as insecticide [7]. Acute intoxication of this pesticide class primarily affects agricultural workers, causing short- and long-term health damages [8]. Clinical conditions include symptoms referred altogether as cholinergic syndrome, embracing among others sialorrhea, diarrhea, bronchial hypersecretion and, in severe cases, mental disorder and even death [8] [9].

Carbaryl intoxication may be confirmed by assaying AChE activity. Spectroscopic assays comprise the standard approach to determine parameters from AChE activity. They are widely used in laboratories around the world. Ellman's method [10] is the usual manner to obtain indirectly the kinetic values of AChE using an artificial substrate, acetylthiocholine (ATCh) [11]. As for several enzymes, the product and substrate of $\mathrm{AChE}$ are not suitable for direct evaluation by UV-VIS absorbance or fluorescence, thereby, the cleavage of ACh as long the reaction process cannot be observed by spectrophotometric techniques. On the other hand, calorimetric assays by isothermal titration calorimetry (ITC), although not as easily performed, return values considerably accurate [12]. The advantages of ITC are the use of enzyme and substrate only, not requiring any additional compound to generate measurable signal, and the possibility to analyze the natural substrate reaction of $\mathrm{AChE}$ [13].

ITC measures the heat exchange in a physical-chemical process and is used typically for binding assays; however, this technique also allows the determination of enzyme kinetics [14]. When a reaction occurs in the assay cell, there is liberation or absorption of heat by the system inside the cell. This causes a drop (exothermic reaction) or increase (endothermic reaction) of power supplied by the electric devices that maintain the temperature inside the cell. This generates a thermogram showing the heat flow $(\mu \mathrm{cal} / \mathrm{s})$ applied by the equipment [12].

When comparing the initial reaction rates $\left(v_{0}\right)$ with the initial substrate concentration, for most of the enzymes studied a rectangular hyperbole arises; those are called Michaelis-Menten (M-M) enzymes [15]. In the literature, linear approaches to evaluate kinetics from M-M enzymes are widely used. However, this linearization lacks precision, i.e. primarily because results obtained at low substrate concentrations overwhelmingly affect the fitted parameters [16].

The present study evaluates the kinetics of AChE by ITC, which allowed the comparison of its activity with the natural (ACh) and the artificial (ATCh) substrates. To achieve better precision, the integrated form of Michaelis-Menten equation was used to determinate experimental kinetic values. Additionally, the 
effect of the pesticide carbaryl, a well-known inhibitor, was also assessed and compared with the conventional methods [5].

\section{Experiment}

\subsection{Materials}

The enzyme acetylcholinesterase, AChE (EC. 3.1.1.7), extracted from electric-fish (Electrophorus electricus), lyophilized, was obtained from Sigma-Aldrich ${ }^{\bullet}$. The substrates used were acetylcholine chloride (A6625) and acetylthiocholine chloride (A5626), both obtained from Sigma-Aldrich ${ }^{\oplus}$.

\subsection{Enzyme}

The concentration of the enzyme stock solution was determined by spectrophotometric assay at $280 \mathrm{~nm}$, using $\epsilon_{280}=125.730 \mathrm{M}^{-1} \cdot \mathrm{cm}^{-1}$, and the result, confirmed by colorimetric assay using Ellman's method [10], was $3.0 \mathrm{mM}( \pm 0.50)$. The concentration of use, $30.0 \mathrm{pM}$, was the same for all experiments and obtained by dilution from that stock. All assays were performed in Tris- $\mathrm{HCl}$ buffer $0.05 \mathrm{M}$ with ionic strength $0.148 \mathrm{M}$ by the addition of $\mathrm{NaCl} 0.05 \mathrm{M}$ and $\mathrm{MgCl}_{2}$ $0.01 \mathrm{M}$. The buffer with the enzyme also contained $0.1 \mathrm{mg} / \mathrm{L}$ of ultrapure bovine serum albumin (Sigma-Aldrich). The experiments were performed at $\mathrm{pH} 7.4$ and $37^{\circ} \mathrm{C}(310.15 \mathrm{~K})$, except when otherwise stated.

\subsection{Substrates and Inhibitor}

The substrates ACh and ATCh were prepared and stocked at $0.1 \mathrm{M}$, and diluted for use in Tris- $\mathrm{HCl}$ buffer $0.05 \mathrm{M}, \mathrm{pH} 7.4$ at $37^{\circ} \mathrm{C}$, with $\mathrm{MgCl} 10 \mathrm{mM}$ and $\mathrm{NaCl}$ $100 \mathrm{mM}$. Carbaryl analytical standard (Brand Sevin ${ }^{\otimes} 99.6 \%$ ) was stored at a concentration of $10 \mathrm{M}$ in a solution of methanol $12.38 \mathrm{M}$ in deionized water. The final concentration of methanol was $0.1 \mathrm{mM}$ in each sample, the same concentration was added to control solutions.

\subsection{ITC Assays}

Assays were performed in isothermal titrating microcalorimeter VP-ITC (Mi$\mathrm{croCal}^{\Phi} \mathrm{GE}$ ). Periodic calibration of the device was conducted by the author and by laboratory team using the procedure described in the equipment manual provided by GE. The default values are described in the literature [17]. The enthalpy was measured by adding the substrates $(4.0 \mathrm{mM} \mathrm{ATCh}$ and $10 \mathrm{mM} \mathrm{ACh}$ ) with 15 successive injections of $8.0 \mu \mathrm{L}$ into the sample cell in the presence of AChE, with an interval of $120 \mathrm{~s}$ between the injections. The reaction was buffered in Tris- $\mathrm{HCl}$ buffer $0.05 \mathrm{M}, \mathrm{NaCl} 0.05 \mathrm{M}$ and $\mathrm{MgCl}_{2} 0.01 \mathrm{M}$ (pH 7.4) at a temperature of $310.15 \mathrm{~K}$. Control experiments were conducted in the absence of AChE.

\subsection{Enzymatic Assay on ITC}

Experimental solutions were degassed with a vacuum pump (ThermoVac, Mi$\mathrm{croCal}^{\oplus}$ ) and let to reach thermal equilibrium for $5 \mathrm{~min}$ prior to experimental run. The heating reference was $30 \mu \mathrm{cal} / \mathrm{s}$, and the stirring speed was $215 \mathrm{rpm}$. To 
analyze the substrate hydrolysis, sequential injections of $1,2,4,6$, and $8 \mu$, the last until the end of the assay, with an interval of $120 \mathrm{~s}$ between them, of $10 \mathrm{mM}$ ACh. For ATCh assay, the same protocol was used.

Todd and Gómez in 2011 [18] developed a method for direct measurement of the rate of product formation, from $\mathrm{d} q / \mathrm{d} t$, the heat flow per time, which is proportional to the power variation supplied by ITC device to the system analyzed, as follows in Equation (1):

$$
\frac{\mathrm{d} q}{\mathrm{~d} t}=\frac{\mathrm{d}[P]}{\mathrm{d} t} \times V \times \Delta_{r} H^{\circ}
$$

where $[P]$ is the molar concentration of product generated, within a certain volume $(V)$. The power variation provided by the temperature controller maintains the temperature at the desired value $(310.15 \mathrm{~K})$. By Rearranging Equation (1), the reaction rate can be determined knowing the change of power provided by the VP-ITC, as the rate of heat generated by the enzyme $(\mathrm{d} q / \mathrm{d} t)$ was equivalent to the variation in instrumental thermal power divided by reaction enthalpy $\left(\Delta_{\mathrm{r}} H^{\prime}\right)$ and volume [18]. Thus, in Equation (2):

$$
\frac{\mathrm{d}[P]}{\mathrm{d} t}=\frac{\mathrm{d} q / \mathrm{d} t}{V \times \Delta_{\mathrm{r}} H^{\circ \prime}}
$$

The variation of enthalpy can be obtained from the area definite by the power curve until it returns to the baseline, after consuming the whole substrate $\left(S_{\text {Total }}\right)$, and it is equal to the total heat of reaction [18], as shown in Equation (3):

$$
\Delta_{r} H^{\circ \prime}=\frac{1}{S_{\text {Total }} \times V} \times \int_{t=0}^{t=\infty} \frac{\mathrm{d} q}{\mathrm{~d} t} \mathrm{~d} t
$$

After these steps, the values of rate and substrate concentration could be used to determine the kinetic parameters, $k_{\text {cat }}$, the first-order rate constant, and $K_{m}$, Michaelis-Menten constant, by applying to Michaelis-Menten Equation (4). It is also possible to determine the thermodynamic parameters of activation by Eyring Equation (5):

$$
\begin{aligned}
& \text { Rate }=\frac{k_{\text {cat }} \times[\text { Enzyme }] \times[\text { Substrate }]}{K_{m}+[\text { Substrate }]} \\
& \ln \frac{k_{\text {cat }}}{T}=\frac{-\Delta^{\ddagger} H}{R} \times \frac{1}{T}+\ln \frac{k_{B}}{h}+\frac{\Delta^{\ddagger} S}{R}
\end{aligned}
$$

where $k_{B}$ is the Boltzmann constant $\left(1.3805 \times 10^{-23} \mathrm{~J} / \mathrm{K}\right), h$ the Planck's constant $\left(6.6256 \times 10^{-34} \mathrm{~J} / \mathrm{s}\right), \Delta^{\ddagger} H$ and $\Delta^{\ddagger} S$ the enthalpy and entropy of activation, $T$ the temperature and $R$ the gas constant $(8.3145 \mathrm{~J} / \mathrm{K} \mathrm{mol})$ [19].

\subsection{Integrated Michaelis-Menten}

Since its formulation, it is possible to write Michaelis-Menten as a superposition of linear and logarithmic function obtained by integrating the equation [20]. In an enzyme kinetic method, it is important observing the concentrations of substrates and products throughout the time from start until the end of reaction. The integrated $\mathrm{M}-\mathrm{M}$ equation is a more appropriate approach for the enzymatic 
reaction, since a usually kinetic reaction is expressed as either product or substrate concentration dependent of time [21]. Main advantages of integrated Michaelis-Menten includes the absence of differentiating data in order to obtain initial velocities, and the ability to determine these initial velocities with high accuracy [22].

Nonetheless, the function is implicit, with several variables, which can be solved by numerical method with the help of basic software programs [21] [22] [23], in Equation (6):

$$
t=-\frac{1}{[\text { Enzyme }] \times k_{\text {cat }}} \times\left\{K_{m} \times \ln \left(S_{0} / S_{0}-P_{t}\right)+P_{t}\right\}
$$

where, $t$ is time observed, $S_{0}$ is the initial substrate concentration and $P_{t}$ is the total product formed until a time $t$, by a certain concentration of enzyme, [Enzyme]. To a reaction with a competitive inhibitor, inhibition constant, $K_{\mathrm{i}}$, can be calculated the knowing the inhibitor concentration, $I$, and the turnover number, $k_{\text {cat, }}$ by Equation (7):

$$
\mathrm{t}=-\frac{1}{[\text { Enzyme }] \times k_{\text {cat }}} \times\left\{K_{m}\left(\frac{S_{0}}{K_{i}}+\frac{I}{K_{i}}+1\right) \ln \left(S_{0} / S_{0}-P_{t}\right)+\left(1-\frac{K_{M}}{K_{I}}\right)\left(P_{t}-I\right)\right\}
$$

\subsection{Analysis}

The calorimetry data were analyzed with Origin 9.0, and with graphs generated with Origin 9.0, GraphPad Prism 6.01 or Microsoft Office Excel 2013.

The experiments were performed in triplicate. For each result, a statistical weighed analysis was used, which took into account the errors associated with each variable. The F-test with Akaike's information criteria (AIC) was used to verify the similarity between regressions. Normality was tested using ShapiroWilk test, given P-values always superior than 0.05 , and Student's $t$-test was used to evaluate two groups. Linear regressions had the weight $1 / y^{2}$ adjusted for each analysis. Data are expressed as mean ( \pm S.E.M.).

\section{Results}

\subsection{Ionization Enthalpy}

The value of the ionization enthalpy $\Delta_{i} H^{\circ}$ was obtained from the literature [24] [25] [26]. Thus, the apparent enthalpy of the reaction, $\Delta_{r} H^{\circ}$, is a sum of the enthalpy of reaction and enthalpy of ionization for a given number of moles. As a result, the value of $\Delta_{i} H^{\circ}=-12.00( \pm 0.66) \mathrm{kJ} / \mathrm{mol}$ was used.

The hydrolysis of ACh by AChE gives a $\Delta_{I} H^{\circ}=-29.76( \pm 2.19) \mathrm{kJ} / \mathrm{mol}$ (Figure $1(\mathrm{a}))$. Similarly, the hydrolisis of ATCh shows a value of $\Delta_{r} H^{\circ}=-24.81( \pm 1.70)$ $\mathrm{kJ} / \mathrm{mol}$ (Figure 1(b)) and it was slightly lower when compared with the value observed with ACh.

\subsection{Activation Energy}

The linear analysis from Eyring equation was used $1 / y^{2}$ as an adjusting of weight, for decreasing the sum of squares of errors, since the $y$-axes, $\ln \left(k_{\text {cat }} / T\right)$, carry 
(a)

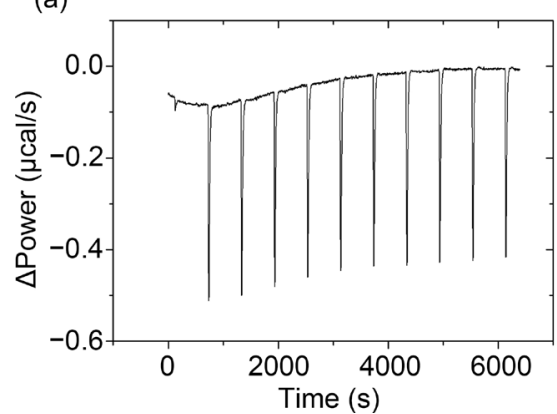

(b)

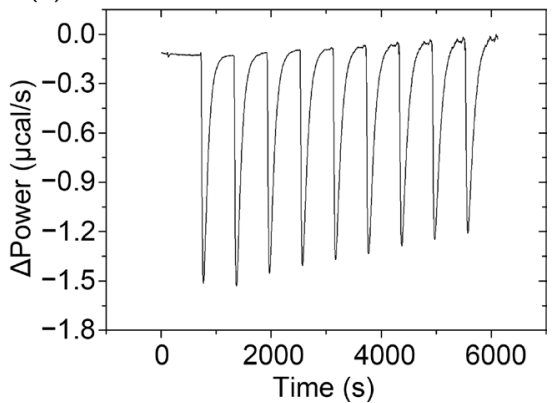

Figure 1. Enthalpy energy obtained from ITC for both substrates. In (a) there is the isothermal curve for ACh. The standard enthalpy was obtained using $4 \mathrm{mM}$ of $\mathrm{ACh}$, in two different injections protocols in the same experiment. The system was allowed to reach thermal equilibrium at $37^{\circ} \mathrm{C}$. After a $120 \mathrm{~s}$ after the equilibrium period, successive injections of $8 \mu \mathrm{l}$ of $40.0 \mathrm{mM}$ ACh were made every $10 \mathrm{~min}$. The enthalpy was calculated by Equation (3) and a baseline corresponding to heat of dilution was subtracted from the data, and correct to the concentration of AChE $30.0 \mathrm{pM}$. In (b) the isothermal curve for ATCh $10.0 \mathrm{mM}$ in a protocol only with $8 \mu \mathrm{L}$ injections by the syringe and titrating them in the cell containing $30.0 \mathrm{pM}$ of AChE, with buffer.

most experimental error than the $x$-axis, $1 / T$. The results from calorimetric assays in different temperatures could be observed in Table 1, notably the pronounced similarity in $\Delta^{\ddagger} G^{\circ}$ values exhibited by both substrates.

The experiment was conducted in different temperatures; thus, it was possible to evaluate the increase in $k_{\text {cat }}$ value with the rising of temperature. The Student's $t$-test shown a similar result for both substrate's $\Delta^{\ddagger} G^{\circ}(p=0.85)$, due to the structural resemblance they have. Nevertheless, the values for $\Delta^{\ddagger} H^{\circ}$ and $T \Delta^{\ddagger} S^{\circ}$ are significantly distinct from each other, displaying a different driven reaction for acetylcholine (Figure 2(a)) compared with acetylthiocholine (Figure 2(b)).

\subsection{Kinetic Parameters}

The simultaneous nonlinear regression analysis (SNLR) uses a concurrent analysis of the data adjusted for M-M equation, the result of inhibition kinetic parameters is seen in Figure 3, and it shows the results obtained for $k_{\text {cat }}$ and $K_{m}$ values. The $k_{\text {cat }}$ could be defined as the number of molecules converted by an enzyme per time unit, or a first-order constant, otherwise, $K_{m}$ is the ratio among direct and inverse reaction constants [19] [27]. Enzymological analysis is typically examined from the point of view of the "catalytic efficiency", wherein the ratio $k_{\text {cat }} / K_{m}$ is seen as a useful indicator of the relative processing power for an enzyme [28]. In presence of different carbaryl concentrations, a classic competitive inhibitor, it is possible to calculate the value of $K_{i}$ [29]. The $K_{i}$ may be thought as the amount of inhibitor required to decrease the reaction; smaller this value, the inhibitor would be more effective [30]. The results for ACh and ATCh are shown in the graphs from Figure 3. The $k_{\text {cat }}$ values for both analyzes were statistically equal when made $F$-test with Akaike's information criterion (AIC) where ACh had a probability $>88.21 \%$ to be equal in all experiments and to ATCh, they had all probability $>61.77 \%$ being equal. 
Table 1. Values of $k_{\text {cat }}$ and activation thermodynamic parameters obtained in ACh and ATCh catalysis kinetics at different temperatures.

\begin{tabular}{cccc}
\hline Substrate & $\Delta^{\ddagger} G^{\circ}(\mathrm{kJ} / \mathrm{mol})$ & $\Delta^{\ddagger} H^{\circ}(\mathrm{kJ} / \mathrm{mol})$ & $T \Delta^{\ddagger} S^{\circ}(\mathrm{kJ} / \mathrm{mol})$ \\
\hline Acetylcholine & $52.02( \pm 0.56)$ & $149.03( \pm 3.99)$ & $96.02( \pm 4.56)$ \\
Acetylthiocholine & $52.41( \pm 1.77)$ & $75.65( \pm 3.91)$ & $23.23( \pm 5.67)$ \\
\hline
\end{tabular}

(a)

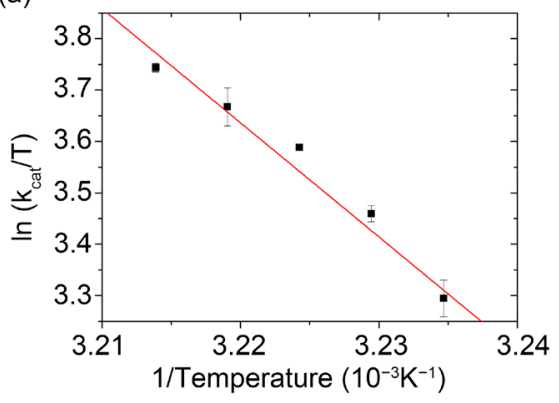

(b)

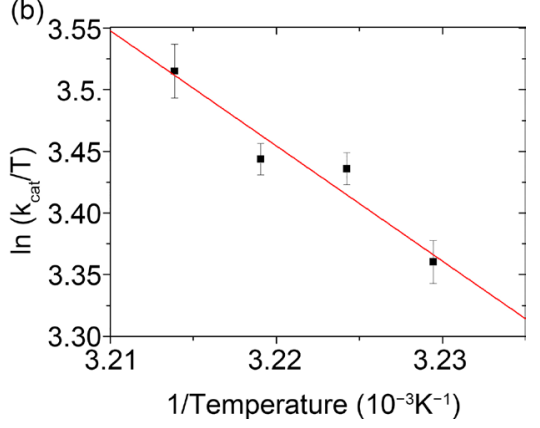

Figure 2. Eyring linear analysis of catalytic constants obtained in different temperatures. Analysis performed at five temperatures for ACh and four for ATCh and adjusted to Eyring equation, Equation (5), where is possible to obtain the thermodynamic parameters of activation, $\Delta^{\ddagger} H$ and $\Delta^{\ddagger} S$. The graph (A) represents the linear regression for $\mathrm{ACh}$ and has a correlation coefficient, $r=-0.9926$. In (B) is the setting for ATCh with $r=-0.9747$.

\subsection{Kinetic Parameters by Integrated Michaelis-Menten Equation}

The integrated form of Michaelis-Menten equation simultaneous analyze various concentration of product formed per time directly by the initial substrate concentration after each injection. This is an iterative nonlinear analysis method and is fitting by the method of least squares, returning the $k_{\text {cat }}$ and $K_{m}$ values. For this, a table is made in a simple program, such as Microsoft Office Excel ${ }^{\circledR}$, so that all values of $t, \mathrm{~S}_{0}, \mathrm{P}_{t}$, and [Enzyme] are aligned in columns side by side [23] [31]. Using the Solver tool, within the program, you can perform the analysis using the Equations (6) and (7). Results are seeing in Table 2.

\section{Discussion}

From the data obtained, the values of $\Delta^{\ddagger} G^{\circ}$ ACh and ATCH are very similar for both groups $(p=0.8426)$, which is plausible since both have a structural similarity, therefore, requiring resembling chemical steps to reach the transition state. However, the replacement of an oxygen by a sulfur in ATCh reflects the difference in the enthalpy factor activation of a substrate to another $(p=0.0001)$, where $\Delta^{\ddagger} H^{\circ}$ for ACh is almost twice that observed for ATCh. This may be due to a greater enzyme specificity for the transition state to the original substrate than for the modified. Although the value of activation entropy, $\Delta^{\ddagger} S^{\circ}$, increases in both cases, comments on this variation must be careful, even in a general base catalysis, as occurred in the enzyme deacylation. This reaction has a transitional state with a lot of spatial freedom, although the variation of entropy in the activated state depends not only on factors intrinsic to the reaction, but also the environment in which this occurs [32]. 

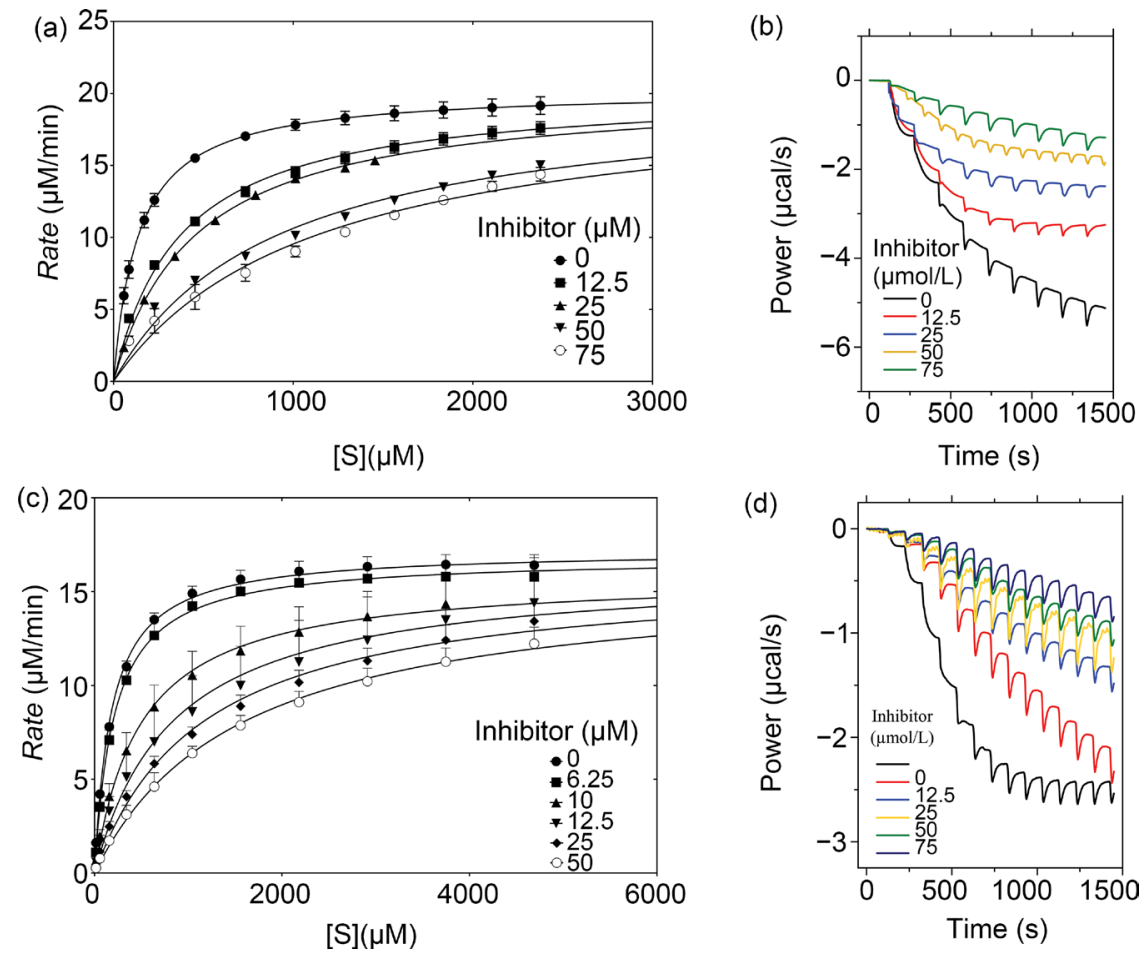

Figure 3. Nonlinear regression analysis of M-M Equation (4) for substrates ACh and ATCh. Kinetic graphs at $310.15 \mathrm{~K}$ in the presence and absence of inhibitor aside their ITC graphs. In (a) SNLR for M-M equation for ACh, (b) ITC assays for ACh, (c) SLNR of M-M equation for ATCh, and (d) ITC assays for ATCh. The concentration of inhibitor is $\mu \mathrm{mol} / \mathrm{L}$. Calorimetric assays were performed with successive injections spaced at $150 \mathrm{~s}$ between them, containing increasing volumes of 1, 2, 4, 6, and $8 \mu$ until finishing, $20 \mathrm{mM}$ $\mathrm{ACh}$ or ATCh, after the equipment has reached thermal equilibrium at $37^{\circ} \mathrm{C}$. The change in thermal power was acquired from the baseline shift, transformed to rate using equation (2). The rate was further used to obtain kinetics values through MM-equation, Equation 4. The SNLR analysis was performed concomitantly, resulting in a $K_{i}$ value, as well the $K_{m}$ and $k_{\text {cat }}$.

Table 2. Results from mathematical analysis using the integrated Michaelis-Menten equation.

\begin{tabular}{|c|c|c|c|c|c|c|c|c|c|}
\hline \multicolumn{5}{|c|}{ Acetylcholine } & \multicolumn{5}{|c|}{ Acetylthiocholine } \\
\hline $\begin{array}{l}\text { Inhibitor } \\
(\mu \mathrm{mol} / \mathrm{L})\end{array}$ & $k_{\mathrm{cat}}\left(\mathrm{s}^{-1}\right)$ & $\begin{array}{c}K_{\mathrm{m}} \\
(\mu \mathrm{mol} / \mathrm{L})\end{array}$ & $\begin{array}{c}k_{c a t} / K_{m} \\
\left(10^{7} \mathrm{M}^{-1} \mathrm{~s}^{-1}\right)\end{array}$ & $\begin{array}{c}K_{i} \\
(\mu \mathrm{mol} / \mathrm{L})\end{array}$ & $\begin{array}{l}\text { Inhibitor } \\
(\mu \mathrm{mol} / \mathrm{L})\end{array}$ & $k_{\text {cat }}\left(\mathrm{s}^{-1}\right)$ & $\begin{array}{c}K_{\mathrm{m}} \\
(\mu \mathrm{mol} / \mathrm{L})\end{array}$ & $\begin{array}{c}k_{c a t} / K_{m} \\
\left(10^{7} \mathrm{M}^{-1} \mathrm{~s}^{-1}\right)\end{array}$ & $\begin{array}{c}K_{i} \\
(\mu \mathrm{mol} / \mathrm{L})\end{array}$ \\
\hline 0 & $11,315.2$ & 138.3 & 8.18 & & 0 & 9050.2 & 148.2 & 6.11 & \\
\hline 12.5 & $11,137.5$ & 216.4 & 5.15 & & 6.35 & 8661.1 & 205.9 & 4.21 & \\
\hline 25.0 & $11,101.5$ & 663.8 & 1.67 & 9.72 & 10.0 & 8908.2 & 222.2 & 4.01 & \\
\hline 50.0 & $11,220.8$ & 914.9 & 1.23 & & 12.5 & 9024.0 & 475.1 & 1.90 & 5.86 \\
\hline 75.0 & $11,180.1$ & 1037.9 & 1.08 & & 25.0 & 9088.3 & 916.5 & 0.99 & \\
\hline-- & -- & -- & -- & & 50.0 & 9007.8 & 1087.0 & 0.83 & \\
\hline
\end{tabular}

The activation value of the standard enthalpy change in the working Cabib and Wilson (1956) [33] was between $140-190 \mathrm{~kJ} / \mathrm{mol}$, however, they had determined that activation energy changes with temperature. As shown, the activation entropy is high, which shows great clutter between enzyme and substrate in 
the transition state, a possible step used by AChE in order to increase the rate of reaction [33]. However, the entropic factor is also preeminent, which would, at a first glance, bringing the idea that the reaction is listless, which is not the case.

The enzyme velocity value using ATCh is lower when compared with $\mathrm{ACh}$, in all analyses. This possibly occurs by the fact the enzyme has more interaction with the transition state from its natural substrate than for the synthetic substrate. As already mentioned, the catalytic efficiency of an enzyme would be given by $k_{\text {cat }} / K_{m}$, which is the value whose second-order constant, $k_{1}$, assumes whether the limiting step of the reaction was the collisional frequency between substrate and enzyme. This could only be assumed when the $k_{\text {cat }}$ value is large enough to not be considered as limiting step, and the approach given to situations where [S] is very small, the second-order constant, $k_{-1}$, for the enzymesubstrate complex dissociation to free enzyme and substrate is negligible.

The values from integrated $\mathrm{M}-\mathrm{M}$ are similar to those obtained by nonlinear regression analysis for both substrates. However, since only one curve was evaluated in each assay for integrated M-M, the deviation observed by the experimental fluctuation cannot be taken into account.

Analyzing all the results, it can be verified a similarity between $K_{m}$ values for both substrates in the absence of inhibitor, motivated by the similarity in affinities to the substrates by the enzyme. As $K_{m}$ is an apparent ratio measured of enzyme-substrate complex formation ratio to substrate catalysis into product, a low $K_{m}$ value means that a lower concentration of substrate is required to achieve maximum rate of kinetics. Similar values of $K_{m}$ explicit similar affinities, but only part of the problem is solved by this interpretation [34].

The values obtained for $K_{i}$ allow to say that the inhibition constants of carbaryl are low and similar for both substrates. This may be a reflection of how carbaryl acts as an inhibitor, entering the active site of the enzyme, interacting with the aromatic amino acids of the anionic site of the enzyme, and blocking the entry of the substrate into the enzyme's gorge [4]. Considering $K_{i}$ as the amount of inhibitor required to slow down the reaction; lower that value, more effective is an inhibitor. Thus, as the specificity of AChE to ACh is large, higher inhibitor concentrations are needed to displace $\mathrm{ACh}$ from the active site, but with ATCh the opposite occurs, a lower concentration of inhibitor is already able to carry carbaryl out from AChE active site, when compared to ACh.

Remarkably, the values from ordinary nonlinear regression are very similar to those obtained by using the integrated $\mathrm{M}-\mathrm{M}$ analysis for both substrates. In recent fields of enzymology, there is the integrated form of the classical Michaelis-Menten equation, where the solution to catalytic constants can be reached directly by the concentration of product formed as a function of time [21]. However, the way found by direct integration of the equation is implicit, where the mathematical process to obtain it is more exhausting. The method used in this work is supported elsewhere [23], where the concentration of product formed in near zero time are measured in function of time without the need to use differential for determining velocities. In this method, information is equal 
to that required to provide a more classical test, but in a single analysis can determine the catalytic constant and varying the inhibitor concentration, also the inhibition constant.

\section{Conclusion}

Although the difference observed in both substrates structure, there is a slightly change of the values of constants because of their distinct interactions with the enzyme. This is also evidenced in different $K_{i}$ values, although very close, the values are higher for $\mathrm{ACh}$, showing that more inhibitor should be necessary to move the natural substrate of the enzyme's active site. An alternative analysis that can save time and return more precise values is the integrated form of the Michaelis-Menten, although in this work, the implicit form was used, requiring more robust computations. The values obtained by this analysis are comparable with those obtained by classical analyses of open explicit form of the equation. Thus, the robustness of ITC enlightens an enzymatic kinetics and thermodynamic parameters values of a reaction, and even better with a more precise mathematical method. Although the traditional spectrophotometric assay is more viable to be used, this work shows comparable kinetics values between $\mathrm{ACh}$ and ATCh, while not precisely identical, and any approximation even if accompanied by an error is correct.

\section{Acknowledgements}

This study is supported by Brazilian Ministry of Health (n. 17217.9850001/12-025). The authors posthumously thank Professor Marcelo M. Santoro for his immeasurable help in this work.

\section{References}

[1] Rotundo, R.L. (2003) Expression and Localization of Acetylcholinesterase at the Neuromuscular Junction. Journal of Neurocytology, 32, 743-766. https://doi.org/10.1023/B:NEUR.0000020621.58197.d4

[2] Wilson, I. and Harrison, M. (1961) Turnover Number of Acetylcholinesterase. Journal of Biological Chemistry, 236, 2292-2295.

[3] Perrier, A.L., Massoulié, J. and Krejci, E. (2002) PRiMA: The Membrane Anchor of Acetylcholinesterase in the Brain. Neuron, 33, 275-285.

https://doi.org/10.1016/S0896-6273(01)00584-0

[4] Dvir, H., Silman, I., Harel, M., Rosenberry, T.L. and Sussman, J.L. (2010) Acetylcholinesterase: From 3D Structure to Function. Chemico-Biological Interactions, 187, 10-22. https://doi.org/10.1016/j.cbi.2010.01.042

[5] Soreq, H. and Seidman, S. (2001) Acetylcholinesterase-New Roles for an Old Actor. Nature Reviews Neuroscience, 2, 294-302. https://doi.org/10.1038/35067589

[6] Pohanka, M., Hrabinova, M., Kuca, K. and Simonato, J.-P. (2011) Assessment of Acetylcholinesterase Activity Using Indoxylacetate and Comparison with the Standard Ellman's Method. International Journal of Molecular Sciences, 12, 2631-2640. https://doi.org/10.3390/ijms12042631

[7] King, A.M. and Aaron, C.K. (2015) Organophosphate and Carbamate Poisoning. Emergency Medicine Clinics of North America, 33, 133-151. 
https://doi.org/10.1016/j.emc.2014.09.010

[8] Fantke, P., Friedrich, R. and Jolliet, O. (2012) Health Impact and Damage Cost Assessment of Pesticides in Europe. Environment International, 49, 9-17.

[9] Bretaud, S., Toutant, J.P. and Saglio, P. (2000) Effects of Carbofuran, Diuron, and Nicosulfuron on Acetylcholinesterase Activity in Goldfish (Carassius auratus). Ecotoxicology and Environmental Safety, 47, 117-124. https://doi.org/10.1006/eesa.2000.1954

[10] Ellman, G.L., Courtney, K.D., Andres, V., Francisco, S. and Featherstone, R.M. (1961) A New and Rapid Colorimetric Determination of Acetylcholinesterase Activity. Biochemical Pharmacology, 7, 88-95. https://doi.org/10.1016/0006-2952(61)90145-9

[11] Riener, C.K., Kada, G. and Gruber, H.J. (2002) Quick Measurement of Protein Sulfhydryls with Ellman's Reagent and with 4,4'-Dithiodipyridine. Analytical and Bioanalytical Chemistry, 373, 266-276. https://doi.org/10.1007/s00216-002-1347-2

[12] Freyer, M.W. and Lewis, E.A. (2008) Isothermal Titration Calorimetry: Experimental Design, Data Analysis, and Probing Macromolecule/Ligand Binding and Kinetic Interactions. Methods in Cell Biology, 84, 79-113. https://doi.org/10.1016/S0091-679X(07)84004-0

[13] Bianconi, M.L. (2007) Calorimetry of Enzyme-Catalyzed Reactions. Biophysical Chemistry, 126, 59-64. https://doi.org/10.1016/j.bpc.2006.05.017

[14] Leavitt, S. and Freire, E. (2001) Direct Measurement of Protein Binding Energetics by Isothermal Titration Calorimetry. Current Opinion in Structural Biology, 11, 560-566. https://doi.org/10.1016/S0959-440X(00)00248-7

[15] Johnson, K.A. and Goody, R.S. (2011) The Original Michaelis Constant: Translation of the 1913 Michaelis-Menten Paper. Biochemistry, 50, 8264-8269. https://doi.org/10.1021/bi201284u

[16] Leatherbarrow, R.J. (1990) Using Linear and Non-Linear Regression to Fit Biochemical Data. Trends in Biochemical Sciences, 15, 455-458. https://doi.org/10.1016/0968-0004(90)90295-M

[17] Wadso, I. and Goldberg, R.N. (2001) Standards in Isothermal Microcalorimetry (IUPAC Technical Report). Pure and Applied Chemistry, 73, 1625-1639. https://doi.org/10.1351/pac200173101625

[18] Todd, M.J. and Gomez, J. (2001) Enzyme Kinetics Determined Using Calorimetry: A General Assay for Enzyme Activity? Analytical Biochemistry, 296, 179-187. https://doi.org/10.1006/abio.2001.5218

[19] Lonhienne, T., Gerday, C. and Feller, G. (2000) Psychrophilic Enzymes: Revisiting the Thermodynamic Parameters of Activation May Explain Local Flexibility. Biochimica et Biophysica Acta, 1543, 1-10. https://doi.org/10.1016/S0167-4838(00)00210-7

[20] Goudar, C.T., Sonnad, J.R. and Duggleby, R.G. (1999) Parameter Estimation Using a Direct Solution of the Integrated Michaelis-Menten Equation. Biochimica et Biophysica Acta, 1429, 377-383. https://doi.org/10.1016/S0167-4838(98)00247-7

[21] Goličnik, M. (2013) The Integrated Michaelis-Menten Rate Equation: DéJà vu or vu jàdé ? Journal of Enzyme Inhibition and Medicinal Chemistry, 28, 879-893. https://doi.org/10.3109/14756366.2012.688039

[22] Bezerra, R.M.F. and Dias, A.A. (2007) Utilization of Integrated Michaelis-Menten Equation to Determine Kinetic Constants. Biochemistry and Molecular Biology Education: A Bimonthly Publication of the International Union of Biochemistry and Molecular Biology, 35, 145-150. https://doi.org/10.1002/bmb.32 
[23] Bezerra, R.M.F., Fraga, I. and Dias, A.A. (2013) Utilization of Integrated Michaelis-Menten Equations for Enzyme Inhibition Diagnosis and Determination of Kinetic Constants Using Solver Supplement of Microsoft Office Excel. Computer Methods and Programs in Biomedicine, 109, 26-31. https://doi.org/10.1016/j.cmpb.2012.08.017

[24] Das, Y., Brown, H.D. and Chattopadhyay, S.K. (1985) Enthalpy of Acetylcholine. Biophysical Chemistry, 23, 105-114. https://doi.org/10.1016/0301-4622(85)80068-5

[25] Fukada, H. and Takahashi, K. (1998) Enthalpy and Heat Capacity Changes for the Proton Dissociation of Various Buffer Components in 0.1 M Potassium Chloride. Proteins. Structure, Function and Genetics, 33, 159-166. https://doi.org/10.1002/(SICI)1097-0134(19981101)33:2<159::AID-PROT2>3.0.CO; 2-E

[26] Goldberg, R.N. (1999) Thermodynamic Quantities for the Ionization Reactions of Buffers. Journal of Physical and Chemical Reference Data, 31, 231. https://doi.org/10.1063/1.1416902

[27] Schnell, S. (2000) Enzyme Kinetics at High Enzyme Concentration. Bulletin of Mathematical Biology, 62, 483-499. https://doi.org/10.1006/bulm.1999.0163

[28] Cornish-Bowden, A. and Cárdenas, M.L. (2010) Specificity of Non-MichaelisMenten Enzymes: Necessary Information for Analyzing Metabolic Pathways. The Journal of Physical Chemistry B, 114, 16209-16213. https://doi.org/10.1021/jp106968p

[29] Forsberg, A. and Puu, G. (1984) Kinetics for the Inhibition of Acetylcholinesterase from the Electric Eel by Some Organophosphates and Carbamates. European Journal of Biochemistry, 140, 153-156. https://doi.org/10.1111/j.1432-1033.1984.tb08079.x

[30] Yung-Chi, C. and Prusoff, W.H. (1973) Relationship between the Inhibition Constant (KI) and the Concentration of Inhibitor Which Causes 50 Per Cent Inhibition (I50) of an Enzymatic Reaction. Biochemical Pharmacology, 22, 3099-3108. https://doi.org/10.1016/0006-2952(73)90196-2

[31] Walsh, S. and Diamond, D. (1995) Non-Linear Curve Fitting Using Microsoft Excel Solver. Talanta, 42, 561-572. https://doi.org/10.1016/0039-9140(95)01446-I

[32] Mulholland, A.J. (2016) Dispelling the Effects of a Sorceress in Enzyme Catalysis. Proceedings of the National Academy of Sciences, 113, 2328-2330. https://doi.org/10.1073/pnas.1601276113

[33] Wilson, I.B. and Cabib, E. (1956) Acetylcholinesterase-Enthalpies and Entropies of Activation. Journal of the American Chemical Society, 78, 202-207. https://doi.org/10.1021/ja01582a056

[34] Eisenthal, R., Danson, M.J. and Hough, D.W. (2007) Catalytic Efficiency and $K_{\text {cat }}$ KM: A Useful Comparator? Trends in Biotechnology, 25, 247-249. https://doi.org/10.1016/j.tibtech.2007.03.010 
Submit or recommend next manuscript to SCIRP and we will provide best service for you:

Accepting pre-submission inquiries through Email, Facebook, LinkedIn, Twitter, etc. A wide selection of journals (inclusive of 9 subjects, more than 200 journals)

Providing 24-hour high-quality service

User-friendly online submission system

Fair and swift peer-review system

Efficient typesetting and proofreading procedure

Display of the result of downloads and visits, as well as the number of cited articles Maximum dissemination of your research work

Submit your manuscript at: http://papersubmission.scirp.org/

Or contact aer@scirp.org 